\title{
Исследование температурного влияния на режим синхронизации мод волоконного резонатора методом дисперсионного Фурье преобразования
}

\author{
$\underline{\text { К.В. Серебренников }}^{*}$, И.В. Петенев, А.Ю. Кохановский \\ Новосибирский государственный университет, г. Новосибирск \\ *E-mail: kospi198@gmail.com
}

DOI: 10.31868/RFL2020.185-186

Волоконные лазеры c синхронизацией мод резонатора на эффекте нелинейного вращения поляризации (НВП) широко распространены в научных лабораториях в качестве источников сверхкоротких импульсов [1]. Относительно простая реализация волоконного лазерного резонатора позволяет получить источник оптических импульсов длительностью фемтосекундного диапазона. К сожалению, стабильность импульсного излучения НВП-лазеров сильно подвержена влиянию окружающей среды, что ограничивает их применение вне научных лабораторий.

Новая волна интереса к НВП-лазерам со стороны научного сообщества связана с развитием алгоритмов машинного обучения, которые позволяют эффективно управлять элементами лазерного резонатора для стабилизации и оптимизации параметров импульсного излучения [2]. Ключевым элементом лазерной системы под управлением алгоритма машинного обучения является система обратной связи, которая определяет результат воздействия элементов управления на параметры оптических импульсов.

Для измерения стабильности работы волоконного лазера, как правило, используют приборы, усредняющие параметры выходных импульсов, что приводит к потере информации межимпульсных флуктуаций. Возможность измерения флуктуаций параметров от импульса к импульсу позволит начать разработку адаптивных лазерных систем с повышенным уровнем стабильности. Наиболее привлекательной методикой для решения поставленной задачи является дисперсионное Фурье преобразование (ДФП) оптических импульсов, которое позволяет измерять оптический спектр отдельного импульса [3].

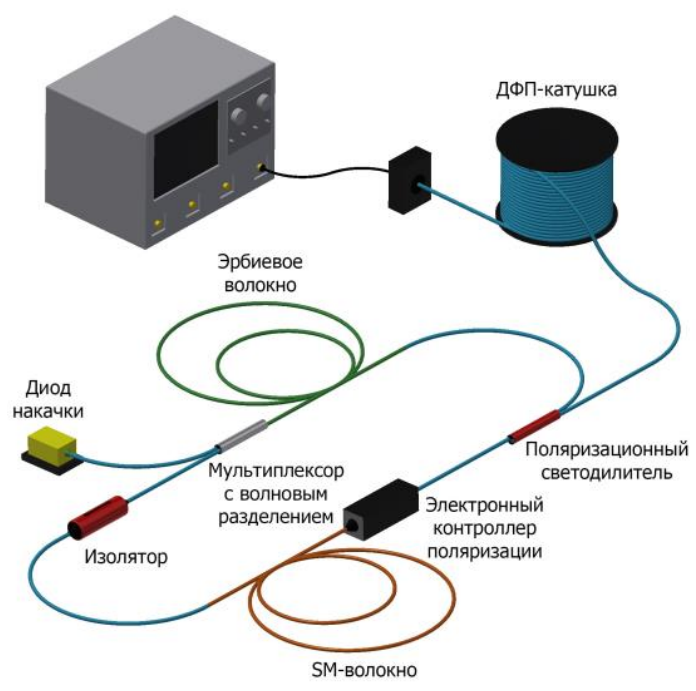

Рис. 1. Схема экспериментальной системы 
В данной работе исследовался волоконный лазер (Рисунок 1). В качестве активной среды использовалась легированное $\mathrm{Er}$ волокно (80 см). Накачка осуществляется лазерным диодом на длине волны 980 нм через WDM. Лазер располагается на терморегулирующей пластине, управляемой ПИД-регулятором. Для генерации режимов использовался метод НВП.

Волоконный лазерный резонатор был помещен на нагревательную плиту, которая обеспечивала управление температурой лазерного резонатора. В режиме стабильной импульсной генерации при температуре $30^{\circ} \mathrm{C}$ были последовательно измерены ДФП - спектры оптических импульсов при повышении температуры резонатора до $41{ }^{\circ} \mathrm{C}$. На (Рисунок 2) представлены основные импульсные режимы лазера, которые устанавливались при нагревании.

a)

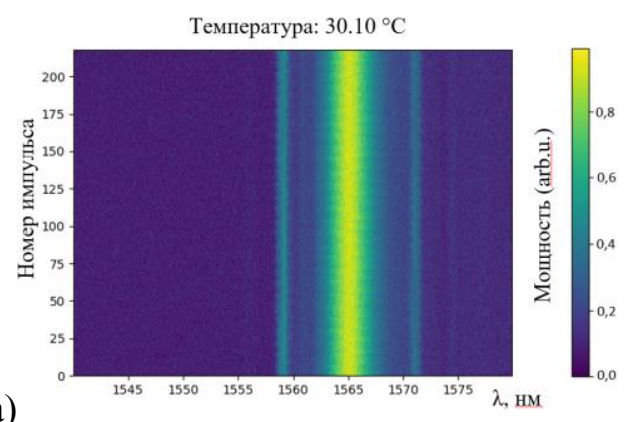

c)

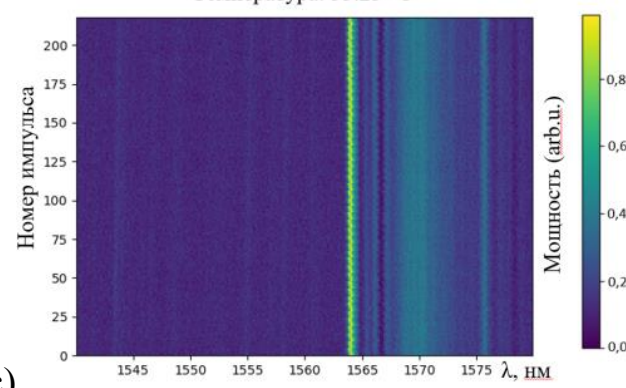

б)
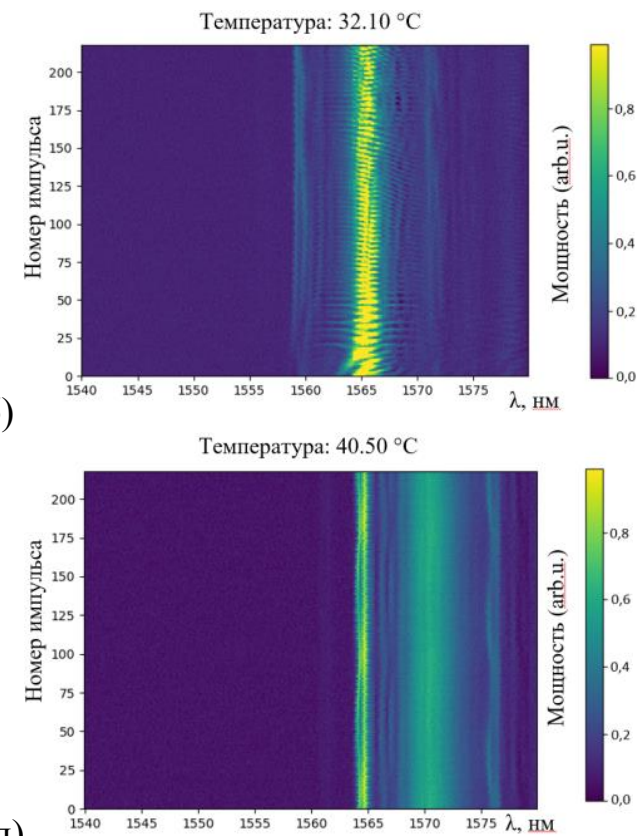

Рис. 2. ДФП-спектры импульсов в зависимости от температуры лазерного резонатора.

Для определения степени флуктуации оптического спектра вычислялось стандартное отклонение ошибки между разностью оптического спектра і-го и 1го импульса. Наименьшее стандартное отклонение у импульсного режима при $30.10{ }^{\circ} \mathrm{C}-30 \mathrm{e}-3$, наибольшее у импульсной генерации при температуре $40.50{ }^{\circ} \mathrm{C}-$ 112е-3 (Рисунок 2 а) и д)). Помимо флуктуаций оптического спектра, ДФП методика позволяет определить флуктуацию энергии от импульса к импульсу. При нагревании резонатора энергия импульсов изменялась в диапазоне 1.2 2.6 пДж, разброс энергий импульсов составлял от $0.1-0.4$ пДж.

Полученные результаты показывают, что методика измерения дисперсионного Фурье-преобразования оптических импульсов позволяет определить межимпульсную флуктуацию энергии и оптического спектра при температурных изменениях лазерного резонатора.

Работа выполнена при поддержке Российского научного фонда (проект № (17-72-30006)).

\section{Литература}

[1] G.P. Agrawal, Nonlinear fiber optics, 4th ed. Academic press, 2007, 539 c.

[2] U.Andral, et al, JOSA B, 33(5), 825 - 833 (2016)

[3] K.Goda, et al, Nat. Photonics, 7, 102 - 112 (2013) 